\title{
IMPACT OF RECENT CHANGES ON LOCAL GOVERNMENT DISCRETION AND ACCOUNTABILITY IN TURKEY*
}

\author{
SON DEĞİŞIKLİKLERİN TÜRKIYYE'DE YEREL YÖNETIMLERİN TAKDİR HAKKI VE \\ HESAP VERİLEBİLIRLIK ÜZERİNDEKİ ETKİSI
}

\section{Serdar YILMAZ ${ }^{\star *}$ Ayşe GÜNER ${ }^{\star * *}$}

\begin{abstract}
The first generation local government reforms in Turkey partially granted discretion to local governments. However, they have largely failed to improve downward accountability towards citizens. In 2012, the government has embarked on the second generation reforms which aimed to achieve economies of scale in municipal service provision through municipal amalgamation. The government redesigned the configuration of municipalities, abolished special provincial administrations in metropolitan municipal jurisdictions and converted villages to neighborhoods of municipalities. This paper extends the earlier analysis on local government discretion and accountability to these recent changes. The main focus of the paper is on fiscal discretion and accountability since these changes have mostly affected the fiscal structure of local governments. Analyzing the data issued by the Ministry of Finance, the preliminary results show that local governments have become more dependent on intergovernmental transfers.
\end{abstract}

Keywords: Local Government Reform; Political, Administrative, Fiscal Discretion and Accountability; Local Government Revenues; Turkey

JEL Classification: H11, H70, H71, R51

Öz

Türkiye'de 2000 yılı sonrasında yapılan yerel yönetim reformları bu idarelere kısmen takdir hakkı tanırken, vatandaşlara yönelik aşağı doğru hesapverilebilirlik açısından önemli ölçüde başarısız kalmıştır. 2012 yılında hükümet yerel yönetimlerin birleştirilmesi yoluyla hizmet sunumunda ölçek ekonomilerini gerçekleştirmek amacıyla ikinci bir düzenlemeyi gerçekleştirmiştir. Bu çerçevede, belediyeleri yeniden yapılandırılmış, büyükşehir belediyesi sınırlarındaki il özel idareleri kaldırılmış ve pek çok köy idaresi mahalleye dönüştürülmüştür. Bu çalışma, daha once Türkiye'de yerel yönetimlerin

* The authors thank Aykut Aydın for excellent research assistance. The findings, interpretations, and conclusions are entirely those of authors, and do not represent the views of the World Bank, its executive directors, or the countries they represent. Corresponding author: Serdar Yilmaz.

** World Bank, Lead Public Sector Specialist, Washington, D.C. E-mail: syilmaz@worldbank.org

** Marmara University, Department of Public Finance, Istanbul. E-mail: aguner@marmara.edu.tr 
takdir yetkisi ve hesap verilebilirliği üzerine yapılan analize parallel olarak, son değişikliklerin etkisini araştırmaktadır. Makale esas olarak yerel yönetimlerin gelirleri konusunda odaklanmaktadır zira yapılan düzenlemeler en çok mali yapıyı etkilemiştir. Maliye Bakanlığı tarafından yayınlanan verilerin analizi ile elde edilen ilk sonuçlar, yerel yönetimlerin yönetimler arası mali transferlere daha fazla bağımlı hale geldiğini göstermektedir.

Anahtar Kelimeler: Yerel Yönetim Reformu; Siyasal, İdari, Mali Takdir ve Hesapverilebilirlik; Yerel Yönetim Gelirleri; Türkiye

JEL Sınıflaması: H11, H70, H71, R51

\section{Introduction}

The Turkish government has implemented major local government reforms since 2004. The first generation reforms were intended to grant more discretion to local governments along the principles of democratic decentralization and improve downward accountability towards citizens (Yilmaz and Guner, 2013). We have argued that these reforms achieved limited success (Yilmaz and Guner, 2013). In this paper, we extend the analysis to the second generation reforms which aimed to achieve economies of scale in municipal service provision through reducing the number local government units significantly. The 2012 legislation on municipalities (law no 6360) ${ }^{1}$ established new metropolitan and district municipalities, extended the municipal services area of metropolitan municipalities, amalgamated municipalities, abolished special provincial administrations in metropolitan municipal jurisdictions and converted villages to neighbourhoods of municipalities.

An important aspect of the second generation reforms is the amalgamation of municipalities without much analysis and consultation. ${ }^{2}$ The main motivation of the government was to achieve economies of scale in municipal services as size economies are expected to improve regional planning and reduce the cost of service delivery in metropolitan areas. However, the changes ended up making municipalities more dependent on central government transfers and created local accountability deficit by removing the benefits of proximity contrary to the subsidiarity principle. In fact, the local government system has become more centralized at the local level, particularly at the metropolitan level (Akilli and Akilli, 2014; Savas-Yavuzcehre, 2016).

This paper contributes to the debate on the size of local governments (Fox and Gurley, 2006) and the growing body of literature presenting the linkages between political, administrative, and fiscal dimensions of decentralization (Smoke, 2015a, 2015b; Local Development International,

1 Law on the Establishment of Fourteen Metropolitan Municipalities and Twentyseven Disticts and Amendments made in Certain Laws and Decrees, No.6360.

2 The preambles of Act No. 6360 describes the main objectives of the law as "avoiding problems about planning and coordination among too many units, benefiting economies of scale, inadequate capacity and financial weakness of small size municipalities..." 
2013; Beris and Serrano-Berthet, 2010; Schneider, 2003). ${ }^{3}$ After this brief introduction section 2 presents a summary of the recent changes in the Turkish local government system. Section 3 and 4 discusses the changes in the political and administrative setting respectively. Section 5 analyses the impact of the 2012 legislation on the fiscal autonomy of local governments. The last section concludes the paper with general observations.

\section{Recent Changes in the Local Government System}

Local government reforms in Turkey began with the introduction of a minimum population criterion of 750,000 in establishing a new metropolitan municipality in $2004 .{ }^{4}$ In 2005 , the government reformed both Special Provincial Administrations (SPAs) and municipalities to achieve better democratic representation at the local level. ${ }^{5}$ Later in 2008, there has been a reduction in the number of municipalities—the number was reduced from 3,225 to 2,950. ${ }^{6}$

In 2012, the government has introduced further changes in the local government system. ${ }^{7}$ These changes kept the structure of local government system intact, but the number of local government units has been reduced significantly. The Law no. 6360 established new metropolitan and district municipalities and reduced the total number of municipalities to 1,397 from 2,950, a 53 percent reduction (see Table 1 and Figure 1). It enforced the population criterion of 750,000 of the 2004 legislation to create new metropolitan municipalities and extended the geographic boundaries of metropolitan municipalities to cover the whole territory of their province. ${ }^{8}$ The total number of metropolitan municipalities increased to 30 from 16. In addition, the law abolished the special provincial administration in these 30 provinces. ${ }^{9}$ On the financing side, the percentage share of metropolitan municipalities' transfers is increased to 6 from $5 .{ }^{10}$

3 It also contributes to case study literature on the balance between local accountability and discretion. Other case studies analysing the impact of accountability and discretion linkages to broader local governance outcomes include Kerala, India (Venugopal and Yilmaz, 2009), Ghana (Yilmaz, 2009), Philippines (Venugopal and Yilmaz, 2013), Burkina Faso (Mahieu and Yilmaz, 2010), Tanzania (Yilmaz and Venugopal, 2010), Ethiopia (Yilmaz and Venugopal, 2011), Pakistan (Aslam and Yilmaz, 2011), Turkey (Yilmaz and Guner 2013), and Sierra Leone (Edwards, Yilmaz and Boex, 2015).

4 The 2004 Metropolitan Municipality Law no.5216 updated the Metropolitan Municipality Law of 1984.

5 They aimed at separation of the executive arm of the SPAs from its deliberative arm. They allowed council members to elect the head of provincial council instead of having the provincial governor (vali), appointed by the central government. In the municipal sector, the Municipality Law no. 5393 devolved additional responsibilities to municipalities and increased the population threshold to establish a new municipality to 5,000 from 2,000 .

6 The Law no. 5747 changed the status of small municipalities that do not meet the minimum population criterion of 2,000 and reorganized municipalities within the borders of metropolitan municipalities.

7 March 2014 local elections had more national political implications than local as they turned into a confidence vote for the ruling party because of the pre-election events of Gezi Park protests and political polarization in the country (Sadioglu, Dede and Yuceyilmaz, 2016).

8 Provinces and districts are the deconcenrated field administrations of the central government.

9 Instead, an investment monitoring and coordination directorate was established in these provinces under the management of the provincial governor.

10 These are derivation based general budget tax revenues collected in their jurisdiction. 
Within metropolitan municipalities, the law extended the boundaries of district municipalities to cover the whole territory of their district (both urban and rural areas), which means the rural share of the area they cover has increased proportionally. ${ }^{11}$ The law also abolished all of the township municipalities within metropolitan municipality jurisdictions. ${ }^{12}$ The villages within the boundaries of the 30 metropolitan municipality provinces were converted into neighbourhoods of district municipalities (approximately 16,000 villages). In provinces other than 30 metropolitan municipal provinces, township municipalities with population less than 2000 were converted into villages. With these changes today more than 75 percent of the population live in 30 metropolitan municipality jurisdictions covering more than 50 percent of the geography of the country.

With the introduction of the second generation local government reforms ${ }^{13}$, Turkey has joined other OECD countries in redrawing the map of local government. ${ }^{14}$ Despite the weaknesses of the theoretical rationale (Fox and Gurley, 2006) and "municipal amalgamation has undergone surprisingly little systemic evaluation" in the world (Blom-Hansen, Houlberg, Serritzlew and Triesman, 2016: 812), the government of Turkey has drastically reduced the number of municipalities through amalgamation-by 53 percent. The policy objective of the reform is described as achieving better territorial management. ${ }^{15}$ However, the optimal size of local governments has been debated in the literature without a consensus on a particular size (Dahl and Tufte, 1973; Hooghe and Mark, 2009; Triesman, 2007). Part of the difficulty is the measurement of economic benefits of amalgamation as certain local services favour large size and others favour smaller size. That is the reason we analyse the impact of the recent changes in Turkey by employing a multi-dimensional local governance framework (Beris and SerranoBerthet, 2010). The diagnostic framework employs political, administrative, and fiscal lenses to analyse the whole intergovernmental architecture. ${ }^{16}$ The paper is based on information gathered during interviews with central and local government authorities by authors and analysis of municipal financial data provided by the Ministry of Finance. ${ }^{17}$

11 Until this law, the policy choice of previous governments was to have municipalities provide urban services and deconcentrated local administrations and SPAs provide services in rural areas of the same province.

12 In the original metropolitan municipality model of 1984, metropolitan municipalities were responsible only for service provision in the urban areas of their province.

13 Although Law no 6360 was issued in 2012, it was put into effect with the March 2014 local elections.

14 See Blom-Hansen, Houlberg, Serritzlew and Treisman (2016) for a review of municipal mergers in the OECD countries over the last five decades.

15 Unlike the past reforms, which were reactionary in nature (reaction to urbanization), this time the government intended to proactively manage the territory.

16 The framework allows analysing each of the three dimensions of intergovernmental design in depth. Otherwise it does not suggest a sequence. For an examination of outcomes of different sequence options see Falleti (2005).

17 The authors conducted semi-structured interviews with central and local government officials in 2016. 
Table I: Types of Municipalities by Population (Before and After the Enforcement of the Law No 6360)*

\begin{tabular}{|c|c|c|c|c|c|c|c|c|}
\hline \multicolumn{2}{|l|}{ Population } & Metropolitan & Provincial & $\begin{array}{l}\text { Metropolitan } \\
\text { District }\end{array}$ & District & Township & Total & Population \\
\hline \multirow{2}{*}{$0-2,000$} & 2012 & & & & 64 & 945 & 1,009 & \\
\hline & 2016 & & & 1 & 40 & 46 & 87 & 143,435 \\
\hline \multirow{2}{*}{$2,000-5,000$} & 2012 & & & & 196 & 845 & 1,041 & \\
\hline & 2016 & & & 12 & 126 & 316 & 454 & $1,352,110$ \\
\hline \multirow{2}{*}{$5,000-10,000$} & 2012 & & & 6 & 181 & 138 & 325 & \\
\hline & 2016 & & & 37 & 98 & 33 & 168 & $1,158,454$ \\
\hline \multirow{2}{*}{$10,000-20,000$} & 2012 & & 1 & 8 & 179 & 43 & 231 & \\
\hline & 2016 & & 1 & 77 & 68 & 2 & 148 & $2,140,602$ \\
\hline \multirow{2}{*}{$20,000-50,000$} & 2012 & & 6 & 20 & 62 & 4 & 92 & \\
\hline & 2016 & & 6 & 146 & 51 & & 203 & $6,400,916$ \\
\hline \multirow{2}{*}{$50,000-100,000$} & 2012 & & 19 & 15 & 50 & 2 & 86 & \\
\hline & 2016 & & 15 & 77 & 14 & & 106 & $7,524,207$ \\
\hline \multirow{2}{*}{$100,000-250,000$} & 2012 & & 29 & 31 & 17 & & 77 & \\
\hline & 2016 & & 26 & 91 & 3 & & 120 & $18,422,275$ \\
\hline \multirow{2}{*}{$250,000-500,000$} & 2012 & 1 & 8 & 44 & & & 53 & \\
\hline & 2016 & & 3 & 58 & & & 61 & $21,805,837$ \\
\hline \multirow{2}{*}{ 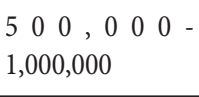 } & 2012 & 5 & 2 & 19 & & & 26 & \\
\hline & 2016 & 10 & & 20 & & & 30 & $21,906,758$ \\
\hline \multirow{2}{*}{$1,000,000+$} & 2012 & 10 & & & & & 10 & \\
\hline & 2016 & 20 & & & & & 20 & $51,630,619$ \\
\hline \multirow{2}{*}{ Total } & 2012 & 16 & 65 & 143 & 749 & 1,977 & 2,950 & \\
\hline & 2016 & 30 & 51 & 519 & 400 & 397 & 1,397 & \\
\hline
\end{tabular}

* The Law no 6360 was issued on December 6, 2012 but came into effect after the March 2014 local elections. Source: Ministry of Interior, General Directorate of Local Authorities, General Activity Report for Local Authorities for 2012 and 2014. 


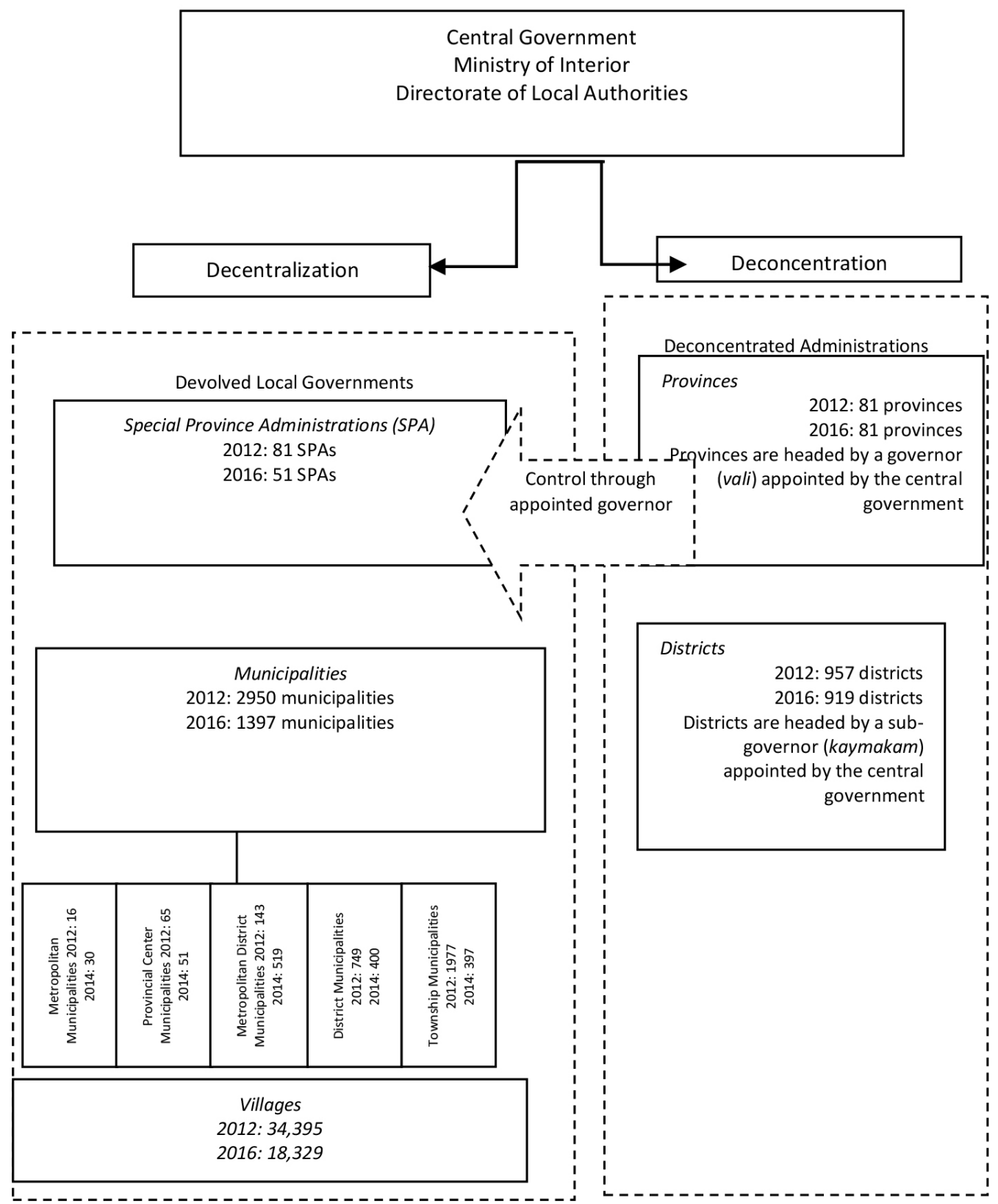

Figure I: Decentralization and Deconcentration Structures in Turkey (Before and After the

Enforcement of the Law No 6360) 


\section{Local Political Setting and Accountaility}

According to our framework, political setting is an important determinant of accountability (Yilmaz et al., 2010). It enables citizens to participate in the political process to hold local elected officials to account. We argue that the recent reforms conflict with democratic principles of the European Charter of Local Self Government ${ }^{18}$ as amalgamation of municipalities and expansion of the metropolitan areas have removed the benefit of proximity-the main tenet of the Charter.

An important issue in terms of political accountability is the way the reforms were introduced. The government employed a centralized top-down approach and abolished nearly half of the municipalities without holding referendum or consulting the citizens, in direct violation of the European Charter. ${ }^{19}$ Thus some criticize this heavy handed approach and describe the changes as centralized decentralization (Arıkboğa, 2013).

In terms of political setting, the biggest change was in the electoral map for metropolitan municipality mayors. With the extension of the metropolitan municipality boundaries, the whole population in the metropolitan provinces vote for metropolitan mayor. This change symbolically brings the elected metropolitan municipality mayor to the same level as the appointed governor of the province. This change politically strengthens municipalities vis-a-vis deconcentrated provincial administrations.

However, the 2012 legislation didn't introduce changes in the relationship between the executive and legislative branches of metropolitan municipalities. The continuation of indirect election of metropolitan municipal councilors by district municipal councilors is a missed opportunity to address representation deficit. ${ }^{20}$

Another major shortcoming of the recent reforms is the failure to address the weaknesses in the political representation to strengthen downward accountability mechanisms. There have been no changes in the existing system which promotes upward accountability of local elected officials towards their national party leadership. Current provincial and municipal council elections are based on party list where national party politics prevail over the preferences and priorities of localities. The national party caucus plays a dominant

18 Turkey is a signatory to the charter which requires compliance with a minimum number of principles that form foundations of local democracy. The Charter lays down the principles of the democratic functioning of communities and establishes the principle of the transfer of competences to local communities - the decentralisation of power towards the level closest to the citizen. This principle is known as the principle of subsidiarity.

19 Article 5 of the Charter about the protection of local authority boundaries says "Changes in local authority boundaries shall not be made without prior consultation of the local communities concerned, possibly by means of a referendum where this is permitted by statute."

20 The metropolitan municipality council is composed of district municipality mayors and a certain amount of council members from these district municipalities. Indirect election of metropolitan municipality councillors weakens direct accountability linkage between citizens and creates a representation deficit (Arıkboğa, 2014). 
role in determining the local political leadership and at times, local development agenda. Furthermore, there have been no changes in the first-past-the-post election system which favors candidates financially supported by political parties and puts independents in a disadvantageous situation. In case of council member elections, the continuing practice of ten-percent threshold hinders representation of all segments of the society through smaller parties and independent candidates. ${ }^{21}$

The reforms have also failed to establish effective public participation and democratic practices (Gul, Kamalak and Kiris, 2016). Social accountability mechanisms to guard the integrity of local democratic governance continue to be defunct. Recalling elected officials requires a lengthy process initiated by local councils. ${ }^{22}$ Term limits for elected officials and quotas for vulnerable groups such as women and ethnic and religious minorities do not exist. In addition, there is a gender inequality at the local level (see Table 2). Out of 30 metropolitan mayors only 3 are women. In municipal councils, the share of woman councillors is a mere 10.7 percent of the total number of councillors. Even though there is an increase in the ratio of women council members in the recent years (see Figure 2 and Table 2), 10.7 percent is a very low figure for a country where 51 percent of the population are women.

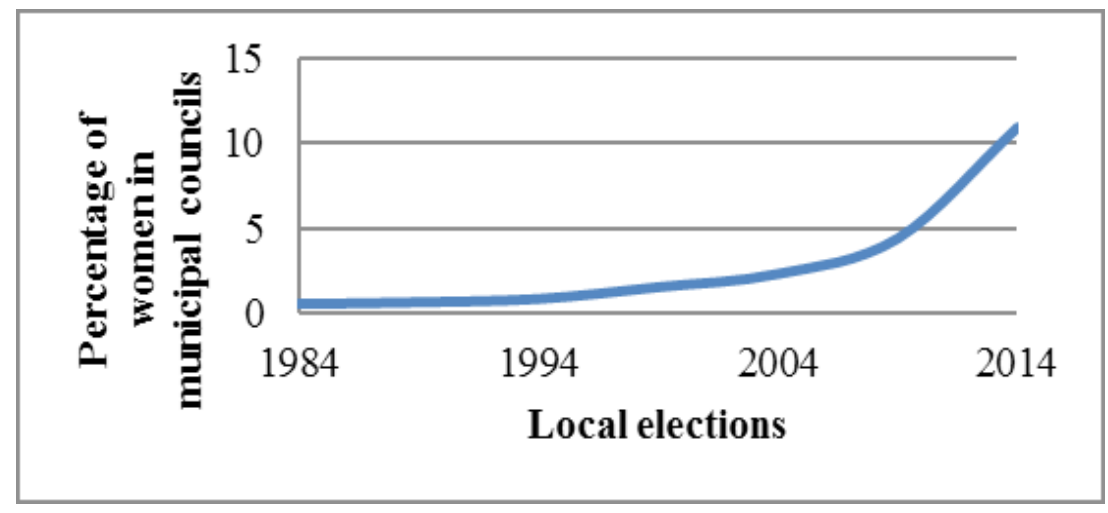

Figure 2: Change in Women Municipal Council Members 1984-20I4

21 Political parties and independents are required to receive at least one tenth of valid votes in an electoral district to be included in rewarding council seats. Political parties that receive less than ten percent of the votes in that local district will have no representation in the council. As a result, there is a huge variation in the average number of votes local councilors receive in each electoral district.

22 In both SPAs and municipalities, if the activity report of the previous year is rejected by their council by a supra majority (three fourths of the council members), the chair of council informs the Ministry of Interior for action against the governor/mayor. In municipalities since mayor is the chair of the council, the vice-chairman of municipal council is responsible to send the council's decision to the governor of that province. Governor transmits the decision to the Council of State together with his/her opinion. The Council of State is the final decision making authority in removing the mayor from the office. 
Table 2: Gender Breakdown of Elected Local Officials (2014)

\begin{tabular}{|l|c|c|c|c|c|}
\hline & Male & \% & Female & \% & Total \\
\hline Metropolitan Mayor & 27 & 90.0 & 3 & 10.0 & 30 \\
\hline Metropolitan District Mayor & 496 & 95.6 & 23 & 5.4 & 519 \\
\hline Provincial Municipal Mayor & 50 & 98.0 & 1 & 2.0 & 51 \\
\hline District and Township Mayor & 784 & 98.4 & 13 & 1.6 & 797 \\
\hline Municipal Council Member & 18,300 & 89.3 & 2,198 & 10.7 & 20,498 \\
\hline Provincial Council Member & 1,191 & 95.2 & 60 & 4.8 & 1,251 \\
\hline Village Headman & 18,085 & 99.7 & 58 & 0.3 & 18,143 \\
\hline Village Council of Elders Member & 79,689 & 98.8 & 1,007 & 1.2 & 80,696 \\
\hline Neighbourhood Headman & 31,013 & 98.0 & 622 & 2.0 & 31,635 \\
\hline Neighbourhood Council of Elders Member & 134,362 & 97.6 & 1,007 & 2.4 & 137,781 \\
\hline
\end{tabular}

Source: Ministry of Interior, Directorate of Local Authorities. Available at http://www.migm.gov.tr/en/publications/LocalAuthoritiesinTurkey.pdf

\section{Local Administrative Discretion and Accountability}

Local administrative discretion and accountability is the indispensable aspect of promoting local economic development. The framework argues that local governments need to be endowed with administrative autonomy in order to be able to respond to local needs effectively (Yilmaz et al., 2010). The second generation reforms failed to underpin the assignment of powers and responsibilities to municipalities and to grant them a large degree of autonomy in managing their affairs. ${ }^{23}$

In terms of administrative reform, the only change was the establishment of a new administrative unit to coordinate central government investments in provinces where SPAs are abolished: Directorate of Investment Monitoring and Coordination (DIMC). DIMCs operate under the purview of provincial governor. ${ }^{24}$ The main responsibility of the directorate is to monitor and coordinate central government ministries' investment and service provision activities in provinces. 25

23 The Constitution empowers the central government over local government affairs. Article 127 grants administrative tutelage power to the central government "in the framework of principles and procedures set forth by law with the objective of ensuring the functioning of local services with the principle of integral unity of the administration, securing uniform public service, safeguarding public interest and meeting local needs in an appropriate manner." The administrative tutelage may be in the form of pre-authorization, approval, execution of services on behalf of municipalities and removal of local leadership from the office. The Minister of Interior may remove mayors and local councillors from office in case of offence related to their duties In addition, all administrative actions of local governments are subject to the inspection of the Ministry of Interior (Yilmaz and Guner, 2013).

24 Governors decide whether they want to head the directorate or assign the responsibility to one of the deputy governors.

25 The legislation defines the organisational structure of DIMCs; it is composed of four technical (investment monitoring; guidance and inspections; strategy and coordination; emergency services) and two administrative (administrative and financial; natural resources, license and culture) departments. 
The abolishment of SPAs within metropolitan municipalities and creation of DIMCs took many by surprise. There had been no analysis and preparation for the transition from SPAs to DIMCs therefore there have been confusion about who would be responsible for ongoing investment projects as well as the civil service cadre of the previous special provincial administrations (Kuran, 2015).

\section{Local Fiscal Discretion and Accountability}

According to our framework, meaningful decentralization reform requires devolving certain level expenditure responsibilities to local government together with financial autonomy to finance local service delivery (Yilmaz et al., 2010). In Turkey, local governments have their devolved expenditure responsibilities; however, the recent reforms failed to address the lack of local taxation power issue. ${ }^{26}$ Instead the reforms increased the intergovernmental transfer amount making local governments more dependent on central government transfers. On the accountability side, upward accountability structures are in place but downward accountability mechanisms are largely absent.

\section{I. Expenditure Assignment}

In Turkey, the share of local governments in total government expenditures and revenues is increasing (see Table 3). ${ }^{27}$

Table 3: Local Government Revenues and Expenditures as a Percentage of GDP (\%)

\begin{tabular}{|l|c|c|c|c|c|c|c|}
\hline & $\mathbf{2 0 1 0}$ & $\mathbf{2 0 1 1}$ & $\mathbf{2 0 1 2}$ & $\mathbf{2 0 1 3}$ & $\mathbf{2 0 1 4}$ & $\mathbf{2 0 1 5}$ & $\mathbf{2 0 1 6}$ \\
\hline Revenues & 3.5 & 3.6 & 3.7 & 3.9 & 3.9 & 4 & 3.4 \\
\hline Expenditures & 3.4 & 3.4 & 3.6 & 4.1 & 3.8 & 4 & 3.8 \\
\hline
\end{tabular}

Source: Ministry of Finance, General Directorate of Budget and Fiscal Control, http://www.bumko.gov. tr/TR, I87/mahalli-idareler.html

26 According to the Constitution, taxation power is only granted to the parliament and the council of ministers has the power to decide tax rate within the limits of a law enacted by the parliament. In 2011, the Constitutional Court ruled that municipalities don't have the same right to decide a tax rate within the limits set by a law. However, the same Constitutional Court ruled in 2013 that municipalities have the right to set a tax rate within the limits set by a law. In 2014, the government issued a decree on setting the minimum and maximum limits for municipal revenues and authorized municipal councils to decide on the rate. However, the decree doesn't necessarily empower municipal councils to make decision single-handedly. Municipal councils decide on rates for municipal revenues and send the decision to the Ministry of Interior, who shares it with the Ministry of Finance and submits it to the Council of Ministers for approval.

27 In Turkey, municipalities have mandatory and discretionary service delivery responsibilities. Mandatory responsibilities include local functions such as city development plan, water and sewage, urban transportation, zoning, geographical and urban information systems, environmental, solid waste collection, parks and recreation, cultural and sports services, municipal police, fire fighting, emergency services, funeral and cemetery services and vocational training. Discretionary responsibilities include social functions such as maintenance of public schools, provision of healthcare, preservation of cultural assets, and protection of historical sites. Service delivery responsibilities of metropolitan municipalities include city development plan, issuance of business permits, urban transportation, maintenance of major transportation arteries, firefighting, water and sewage, cemetery and other various services. 
The recent reforms failed to address the confusion in service delivery responsibilities between metropolitan and district municipalities. In metropolitan areas, the municipality law assigns certain local services to district municipalities. However, district municipalities within the boundaries of metropolitan municipalities and metropolitan municipalities have certain common responsibilities. It is confusing for citizens who are responsible from which service as district and metropolitan municipalities have concurrent responsibilities.

In addition, the extension of geographic boundaries of metropolitan and district municipalities without changing service delivery responsibilities defies the logic of the original metropolitan governance model in achieving economies of scale in service provision (Arıkboğa, 2013). Although the abolishment of small township municipalities and extension of geographic boundaries of district and metropolitan municipalities helped to achieve economies of scale in service provision; the division of service delivery responsibilities between metropolitan and district municipalities has not changed. The original 1984 design of metropolitan model intentionally established a hierarchy by putting the metropolitan municipality over district municipalities to achieve economies of scale and assigned certain services, like landfill management, construction and maintenance of main arteries, to the metropolitan municipality. However, the extension of geographic boundaries of district municipalities without changing the service delivery responsibilities appears to question the logic of the original municipal governance model (Arıkboğa, 2013). One can easily argue that the economies of scale argument to have metropolitan municipalities doesn't hold any more with these changes. The geographic and population size of district municipalities have been enlarged enough to achieve economies of scale in the provision of services originally assigned to metropolitan municipalities.

\subsection{Revenue Assignment}

Decentralization of expenditure responsibilities brings with it the need for establishing a local revenue system which conforms to theoretically-accepted normative principles. The Turkish local government system has mixed properties according to the three-step evaluation proposed by Ebel and Taliercio (2005). According to their framework, the initial step is the application of public finance theory. From the public finance theory perspective, the Turkish local revenue system has stabilization, international trade and insurance properties. The central government keeps the broad-based taxes on consumption (value-added tax) and income (personal income and corporate income) for itself as stabilization tools. In terms of international trade, the only authority controlling international trade taxes is the central government. Levying customs duties is the central government prerogative. Central government also performs insurance functions in case of exogenous shocks.

The second step is the application of benefits framework. The benefits logic argues that local revenue system should be designed to have the beneficiaries of local services to pay for them. The benefits of local services can either be specific to the direct user or generalized to a broader 
community. In Turkey, local governments have both specific benefit revenues (user charges and fees) and generalized benefits taxation tools (property tax). These are own source revenues of local governments. On average, nearly 40 percent of local government revenues come from their own sources (see Table 4). However, there is a big difference between municipalities and SPAs. For SPAs own source revenues are a negligible amount. They are heavily dependent on conditional transfers (see Table 5). Whereas, for municipalities own source revenues ${ }^{28}$ are nearly half of their revenues; the other half is unconditional block transfers. Conditional transfers are less than one percent of total municipal revenues.

Table 4: Local Government Revenues (\%)

\begin{tabular}{|l|l|l|l|l|l|l|l|}
\hline & $\mathbf{2 0 1 0}$ & $\mathbf{2 0 1 1}$ & $\mathbf{2 0 1 2}$ & $\mathbf{2 0 1 3}$ & $\mathbf{2 0 1 4}$ & $\mathbf{2 0 1 5}$ & $\mathbf{2 0 1 6}$ \\
\hline Own source revenue & 38.60 & 38.22 & 37.90 & 37.99 & 39.63 & 35.79 & 36.92 \\
\hline Unconditional transfers & 46.40 & 45.93 & 47.43 & 45.82 & 52.24 & 56.91 & 55.87 \\
\hline Conditional transfers & 15.00 & 15.85 & 14.67 & 16.19 & 8.13 & 7.30 & 7.21 \\
\hline Total & 100 & 100 & 100 & 100 & 100 & 100 & 100 \\
\hline
\end{tabular}

Source: Calculated by the authors from data on www.muhasebat.gov.tr (Ministry of Finance General Directorate of Public Accounts)

Table 5: Municipal and SPA Revenues (\%)

\begin{tabular}{|l|l|l|l|l|l|l|l|l|l|l|l|l|l|l|l|l|l|}
\hline & \multicolumn{3}{l}{$\mathbf{2 0 1 0}$} & $\mathbf{2 0 1 1}$ & $\mathbf{2 0 1 2}$ & $\mathbf{2 0 1 3}$ & \multicolumn{2}{l|}{$\mathbf{2 0 1 4}$} & \multicolumn{2}{l|}{$\mathbf{2 0 1 5}$} & \multicolumn{2}{l|}{$\mathbf{2 0 1 6}$} \\
\cline { 2 - 16 } & SPA & $\mathbf{M}$ & SPA & $\mathbf{M}$ & SPA & M & SPA & M & SPA & M & SPA & M & SPA & M \\
\hline $\begin{array}{l}\text { Own source } \\
\text { revenue }\end{array}$ & 7 & 48 & 8 & 47 & 8 & 46 & 8 & 47 & 8 & 43 & 9 & 39 & 8 & 40 \\
\hline $\begin{array}{l}\text { Unconditional } \\
\text { transfers }\end{array}$ & 28 & 52 & 25 & 52 & 27 & 53 & 24 & 52 & 25 & 55 & 29 & 60 & 30 & 59 \\
\hline $\begin{array}{l}\text { Conditional } \\
\text { transfers }\end{array}$ & 65 & 1 & 68 & 1 & 65 & 1 & 68 & 1 & 67 & 1 & 63 & 2 & 63 & 1 \\
\hline Total & 100 & 100 & 100 & 100 & 100 & 100 & 100 & 100 & 100 & 100 & 100 & 100 & 100 & 100 \\
\hline
\end{tabular}

28 Municipalities have four different types of own revenues: taxes (on property, environmental cleaning, advertisement, communications, electricity and gas consumption and fire insurance), duties (on occupation license, holiday work license, spring waters license, town-crier, animal slaughter inspection and supervision, measure and weighing instruments inspection, building construction, business license, inspection and license report and health certificate), expenditure contribution charges (for road, sewage and water infrastructure construction) and fees (for all services performed upon the request of individual citizens that are not subject to duties and expenditure contribution shares). In addition to these municipalities have revenue income from profits of municipality owned corporations, rental income, and income from the sales of municipal assets. Municipalities have different levels of control over these revenue sources in terms of defining the base, setting the rate and collection autonomy within the constitutional limitations. Overall local governments have very limited autonomy in defining the base and rate of their own source revenue items. 
SPA= Special Province Administration; M=Municipality

Source: Calculated by the authors from data on www.muhasebat.gov.tr (Ministry of Finance General Directorate of Public Accounts)

The last step of the analysis is the revenue mobilization capacity. In a well-functioning local government finance system local governments have access to buoyant sources of revenue to finance their service delivery obligations. ${ }^{29}$ In Turkey, the buoyancy of local government revenues has always fluctuated significantly from one year to another (Guner and Yilmaz, 2006). It seems that the fluctuation still continues after the 2012 legislation (see Table 6). This fluctuation in local revenues is a source of instability in revenues for local governments; it makes budget planning difficult for them.

Table 6: Buoyancy of Municipal and SPA Revenues

\begin{tabular}{|l|l|l|l|l|l|l|l|l|l|l|l|l|}
\hline & \multicolumn{2}{|c|}{2011} & \multicolumn{2}{c|}{2012} & \multicolumn{2}{c|}{2013} & \multicolumn{2}{c|}{ 2014 } & \multicolumn{2}{c|}{ 2015 } & \multicolumn{2}{c|}{ 2016 } \\
\cline { 2 - 15 } & SPA & M & SPA & M & SPA & M & SPA $^{1}$ & M & SPA & M & SPA & M \\
\hline Own source revenue & 1.26 & 0.98 & 1.69 & 0.94 & 2.04 & 2.03 & -4.48 & 0.60 & 1.44 & 0.32 & -0.66 & 1.47 \\
\hline Unconditional transfers & 1.03 & 1.08 & 1.34 & 1.41 & 1.48 & 1.66 & -4.53 & 2.05 & 2.37 & 2.05 & 0.71 & 0.88 \\
\hline Conditional transfers & 1.37 & 2.46 & 0.30 & -1.72 & 3.14 & 4.31 & -4.85 & 7.60 & 0.50 & 2.02 & 0.36 & 0.86 \\
\hline
\end{tabular}

$\mathrm{SPA}=$ Special Province Administration; $\mathrm{M}=$ Municipality

Source: Calculated by the authors from data on www.muhasebat.gov.tr (Ministry of Finance General Directorate of Public Accounts) and www.tuik.gov.tr (Turkish Statistical Institute)

The composition of municipal revenues significantly differs across different categories of municipalities (see Table 7). Although transfers constitute the main bulk of revenue for all categories of municipalities, metropolitan municipalities are more dependent on transfers than other types of municipalities. The dependence on transfer revenues for metropolitan municipalities has increased since the 2012 legislation (which went into force in April 2014). In 2015 more than 75 percent of metropolitan municipal revenues came from transfers. On a positive note, these are unconditional transfers (the share of conditional transfers is less than 3 percent of total revenues), thus municipalities have the power to use transfer revenues according to their own needs and choices.

In terms of own source revenues, interestingly enough, smaller municipalities, such as district/ township and provincial center municipalities, raise more own source revenues than larger more urbanized metropolitan municipalities. This is counterintuitive. One would expect that municipalities in metropolitan jurisdictions would be able to raise more own source revenues than smaller municipalities in rural areas. This is a direct result of intergovernmental fiscal policy choices of the central government.

29 Buoyancy is an indicator to measure efficiency and responsiveness of revenue mobilization in response to growth in the gross domestic product. 
Table 7: Breakdown of Municipal Revenues (2010-2015) (\%)

\begin{tabular}{|c|c|c|c|c|c|}
\hline & & $\begin{array}{r}\text { Conditional } \\
\text { Transfers (A) }\end{array}$ & $\begin{array}{l}\text { Unconditional } \\
\text { Transfers } \\
\text { (B) }\end{array}$ & $\begin{array}{l}\text { Own Source } \\
\text { Revenues (C) }\end{array}$ & $\begin{array}{c}\text { Total } \\
\text { Revenues } \\
(\mathrm{A})+(\mathrm{B})+(\mathrm{C})\end{array}$ \\
\hline \multirow[t]{3}{*}{2010} & MM & 0.27 & 65.52 & 34.41 & 100 \\
\hline & D\&T & 1.19 & 42.06 & 56.75 & 100 \\
\hline & $\mathrm{PC}$ & 0.66 & 46.69 & 52.65 & 100 \\
\hline \multirow[t]{3}{*}{2011} & MM & 0.55 & 66.64 & 30.08 & 100 \\
\hline & $\mathrm{D} \& \mathrm{~T}$ & 1.22 & 41.72 & 57.06 & 100 \\
\hline & PC & 0.98 & 48.96 & 50.05 & 100 \\
\hline \multirow[t]{3}{*}{2012} & MM & 0.29 & 70.02 & 30.33 & 100 \\
\hline & $\mathrm{D} \& \mathrm{~T}$ & 1.05 & 41.66 & 57.29 & 100 \\
\hline & $\mathrm{PC}$ & 0.62 & 47.81 & 51.57 & 100 \\
\hline \multirow[t]{3}{*}{2013} & MM & 0.33 & 68.05 & 31.97 & 100 \\
\hline & D\&T & 1.35 & 40.58 & 58.06 & 100 \\
\hline & $\mathrm{PC}$ & 0.61 & 50.17 & 49.23 & 100 \\
\hline \multirow[t]{3}{*}{2014} & MM & 0.41 & 67.19 & 32.58 & 100 \\
\hline & $\mathrm{D} \& \mathrm{~T}$ & 2.63 & 42.93 & 54.44 & 100 \\
\hline & $\mathrm{PC}$ & 1.19 & 55.35 & 43.46 & 100 \\
\hline \multirow[t]{3}{*}{2015} & MM & 0.65 & 75.60 & 23.75 & 100 \\
\hline & D\&T & 2.52 & 44.46 & 53.01 & 100 \\
\hline & PC & 1.52 & 55.63 & 42.85 & 100 \\
\hline \multirow[b]{3}{*}{2016} & MM & 0.49 & 75.42 & 24.09 & 100 \\
\hline & $\mathrm{D} \& \mathrm{~T}$ & 2.66 & 41.81 & 55.53 & 100 \\
\hline & $\mathrm{PC}$ & 1.80 & 54.86 & 43.34 & 100 \\
\hline
\end{tabular}

$\mathrm{MM}=$ Metropolitan Municipalities; D\&T=District and Township Municipalities (including district municipalities within the boundaries of metropolitan municipalities); PC= Provincial Center Municipalities.

Source: Calculated by the authors from data on www.muhasebat.gov.tr (Ministry of Finance General Directorate of Public Accounts).

\subsection{Financing the Fiscal Gap: Inter-governmental Transfer System Design}

The Turkish intergovernmental transfer system has desirable features of predictability, simplicity, transparency as well as interregional equity (Yilmaz and Guner, 2013). The transfers from central government to local governments consist mainly of formula-based block grants which are buoyant and predictable (Guner and Yilmaz, 2006). There is a formula for both the transfer pool amount (vertical imbalance) and allocation to individual local governments (horizontal imbalance).

The Municipalities Law no 6360 introduced major changes in the percentages of central government transfers (block grants) going to local authorities (see Table 8). With the reduction in the number of special provincial administrations, the law reduced the percentage of general tax revenues going to SPAs from 1.15 percent to 0.5 percent. In return, the share of district municipalities in metropolitan areas increased from 2.5 percent to 4.5 percent. Whereas, the share of municipalities outside of metropolitan jurisdiction was reduced from 2.85 percent to 1.5 percent (see Table 8 ). 
Table 8: Block Grants to Local Governments in Pre-6360 and Post-6360 Periods

\begin{tabular}{|c|c|c|}
\hline & Pre Municipalities Law no 6360 & Post Municipalities Law no 6360 \\
\hline $\begin{array}{l}\text { Special Provincial } \\
\text { Administrations }\end{array}$ & $\begin{array}{l}1.15 \text { percent of general budget tax } \\
\text { revenues were transferred to } 81 \text { SPAs } \\
\text { based on population (50\%), geographic } \\
\text { size }(10 \%) \text {, number of villages } \\
(10 \%), \text { rural population }(15 \%) \text { and } \\
\text { development index }(15 \%) . \\
\end{array}$ & $\begin{array}{l}0.5 \text { percent of general budget tax } \\
\text { revenues are transferred to 51 SPAs } \\
\text { based on population (50\%), geographic } \\
\text { size }(10 \%) \text {, number of villages } \\
(10 \%) \text {, rural population }(15 \%) \text { and } \\
\text { development index }(15 \%) \text {. }\end{array}$ \\
\hline $\begin{array}{l}\text { Municipalities within } \\
\text { Metropolitan Areas }\end{array}$ & $\begin{array}{l}2.5 \text { percent of general budget } \\
\text { tax revenues were transferred to } \\
\text { municipalities within metropolitan } \\
\text { municipality jurisdictions according to } \\
\text { their population. These municipalities } \\
\text { shared their transfer revenue with their } \\
\text { respective metropolitan municipality } \\
(30 \%) \text { and water and sewage authority } \\
(10 \%) \text { in their metropolitan area. }\end{array}$ & $\begin{array}{l}\text { 4.5 percent of general budget } \\
\text { tax revenues are transferred to } \\
\text { municipalities within metropolitan } \\
\text { municipality jurisdictions according to } \\
\text { their population }(90 \%) \text { and geographic } \\
\text { size }(10 \%) \text {. These municipalities } \\
\text { share their transfer revenue with their } \\
\text { respective metropolitan municipality } \\
(30 \%) \text { and water and sewage authority } \\
(10 \%) \text { in their metropolitan area. }\end{array}$ \\
\hline $\begin{array}{l}\text { Municipalities outside } \\
\text { of Metropolitan Areas }\end{array}$ & $\begin{array}{l}2.85 \text { percent of general budget } \\
\text { tax revenues were transferred to } \\
\text { municipalities outside of metropolitan } \\
\text { municipality jurisdictions according } \\
\text { to their population }(80 \%) \text { and } \\
\text { development index }(20 \%) \text {. }\end{array}$ & $\begin{array}{l}1.50 \text { percent of general budget } \\
\text { tax revenues are transferred to } \\
\text { municipalities outside of metropolitan } \\
\text { municipality jurisdictions according } \\
\text { to their population }(80 \%) \text { and } \\
\text { development index }(20 \%) .\end{array}$ \\
\hline
\end{tabular}

Source: Adopted from Arıkboğa (2015).

The new law also revamped the intergovernmental transfers system for the metropolitan municipalities (see Table 9). It increased the total resources going to metropolitan municipalities by increasing the percentage from 5 percent to 6 percent. But only 60 percent of these resources go directly to metropolitan municipalities on derivation basis and the rest is distributed across all metropolitan municipalities based on population (70 \%) and geographic size (30\%).

Table 9: Intergovernmental Transfers for Metropolitan Municipalities

\begin{tabular}{|l|l|}
\hline Pre Municipalities Law no 6360 & Post Municipalities Law no 6360 \\
\hline
\end{tabular}

1.Derivation Based Transfers: 5 percent of general budget 1.Derivation Based Transfers: 6 percent of general budget tax revenues collected in metropolitan jurisdictions were tax revenues collected in metropolitan jurisdictions are transferred to 16 metropolitan municipalities based on two transferred to 30 metropolitan municipalities based on criteria: (i) place (70\%) and (ii) population (30\%). In other two criteria: (i) place $(60 \%)$ and (ii) the rest (40\%) with words, out of 5 percent of general government revenues population (\% 70) and geographic size (30\%). In other collected in one metropolitan municipality jurisdiction words, out of 6 percent of general government revenues only $70 \%$ of those revenues stay in that metropolitan collected in one metropolitan municipality jurisdiction municipality. The remaining $30 \%$ is redistributed to all only $60 \%$ of those revenues stay in that metropolitan metropolitan municipalities on population basis. $\quad$ municipality. The remaining $40 \%$ is redistributed to all 2.Shares from district municipalities: District municipalities metropolitan municipalities based on population (70 \%) within metropolitan jurisdictions transferred 30 percent of and geographic size (30\%).

their block grants to metropolitan municipalities.

2.Shares from district municipalities: District municipalities within metropolitan jurisdictions transferred 30 percent of their block grants to metropolitan municipalities.

Source: Adopted from Arıkboğa (2015). 


\subsection{Local Government Borrowing}

Local governments are allowed to borrow within the rules set by law and under the supervision of the central government (in the case of foreign borrowing). The Municipalities Law no 6360 made no changes on borrowing. In Turkey, over 95 percent of the local government debt stock is carried by municipalities (see Table 10). Metropolitan municipalities are the main borrowers followed by district municipalities due to the infrastructure investment needs of the urban jurisdictions (see Table 11).

Table 10: Debt Stock of Local Governments (\%)

\begin{tabular}{|l|l|l|l|}
\hline & SPAs & Municipalities & Total \\
\hline 2010 & 3,06 & 96,94 & 100 \\
\hline 2011 & 4,13 & 95,87 & 100 \\
\hline 2012 & 3,72 & 96,28 & 100 \\
\hline 2013 & 4,18 & 95,82 & 100 \\
\hline 2014 & 1,88 & 98,12 & 100 \\
\hline 2015 & 2,04 & 97,96 & 100 \\
\hline
\end{tabular}

Source: Calculated by the authors from data on www.muhasebat.gov.tr (Ministry of Finance General Directorate of Public Accounts).

Table I I: Debt Stock of Municipalities by Type (\%)

\begin{tabular}{|l|c|c|c|c|}
\hline & M & PC & D\&T & Total \\
\hline 2010 & 59,59 & 8,62 & 31,8 & 100 \\
\hline 2011 & 55,37 & 10,28 & 34,35 & 100 \\
\hline 2012 & 52,33 & 10,98 & 36,69 & 100 \\
\hline 2013 & 48,96 & 11,46 & 39,58 & 100 \\
\hline 2014 & 54,59 & 7,22 & 38,19 & 100 \\
\hline 2015 & 54,94 & 7,06 & 38,01 & 100 \\
\hline
\end{tabular}

M=Metropolitan Municipalities; D\&T=District and Township Municipalities (including district municipalities within the boundaries of metropolitan municipalities); PC= Provincial Center Municipalities.

Source: Calculated by the authors from data on www.muhasebat.gov.tr (Ministry of Finance General Directorate of Public Accounts).

\subsection{Making Local Finances Publicly Accountable}

In Turkey, the downward accountability linkages between citizens and local governments are very weak. There are important barriers in front of accessing financial information in the municipal sector. The two issues that are particularly problematic: debt deductions from transfer revenues and municipality owned enterprises. 
In case of debt delinquency on part of municipalities, the Provinces Bank (İlbank A.Ş.) is used by the government as a device for deduction at the source. ${ }^{30}$ In the past, the Provinces Bank provided information about the amount of transfers to local governments and the deduction amounts by municipality. However, after the change of the status of the Provinces Bank to a joint stock company in February 2011, it has stopped providing detailed information about deductions at the source. ${ }^{31}$ Although Turkey has enacted a Right to Information Act in 2003, the Provinces Bank hides behind the Banking Law in rejecting the requests for information. More importantly, central government's power of deduction at the source without any early warning has a detrimental effect on the stability and predictability of the transfer system.

In terms of financial information, another problematic area is the finances of municipality owned enterprises. Financial information about municipality owned enterprises is not publicly available as they are regulated by the commercial law.

As for local participation, there are no mechanisms to involve citizens in local planning and budgeting processes. More importantly, recent studies documented patronage politics in municipalities. Municipalities use their power in the delivery of public goods and services to pursue distributive politics (Bayraktar and Altan, 2013). In addition, they engage in vote buying by distributing appliances, coal and food baskets (Eligur, 2009). Furthermore, in a recent study, Aytac (2014) analyzed the distributive politics features of another central government program, Turkey's Conditional Cash Transfer (CCT) program. He documents how the program is used as a tool for patronage politics by its executive committee through the discretionary enrollment at the local level. In this setting, the control of metropolitan municipalities is particularly important to increase possibilities for winning national elections (Sayari, 2014).

An important tool in meddling with local affairs is the Mass Housing Administration (Toplu Konut İdaresi-TOKI). The ruling party uses TOKI as a tool for patronage politics. ${ }^{32}$ The involvement of TOKI in electoral politics is very visible at the local level. TOKI plays a key role in providing jobs, contracts and subsidized housing at the local level. By using time series data across 900 municipalities, Marschall, Aydogan and Bulut (2016) shows the linkage between TOKI housing

30 The intergovernmental transfers are channeled to municipalities and SPAs through the Provinces Bank, except metropolitan municipality transfers which are directly deposited to the metropolitan municipalities' account by the Ministry of Finance. In case of debt delinquency on part of municipalities, the Provinces Bank is used for deductions up to 40 percent from their transfer revenues. The decision on the percentage rests with the council of ministers.

31 Only a global figure of the transfers to SPAs and municipalities is published in their Annual Report.

32 The ruling party government increased the power and autonomy of TOKI over the years and eventually moved it directly under the authority of the Prime Minister. The government also amended the Public Management and Control Law (No. 5018) exempting TOKI from auditing requirements. With enhanced powers, TOKI has a market share of 10 percent in construction sector. TOKI and municipalities have the authority to make decisions related to the size, type and plans of housing projects. Therefore, both TOKI and municipalities have considerable discretion over huge infrastructure investments affecting the housing, employment, and amenities of local residents. Gurakar (2016) documents how construction firms receiving contracts from TOKI are related to the ruling party. 
projects and likelihood of the ruling party wining the elections. According to their analysis, in districts where TOKI makes investments, the likelihood of the ruling party's wining local elections is greatly enhanced.

\section{Conclusion}

Municipal amalgamation has attracted significant attention as a remedy for inefficient service delivery. However, there seems to be a marked disjoint between theory and empirical evidence. Although countries consider municipal amalgamation as a means to lower service delivery costs, empirical findings suggest that benefits and costs of an amalgamation is country specific (Fox and Gurley, 2006). As the Turkish case illustrates, local government reform is a complex process with impact on political, administrative and fiscal dimensions. Partial reforms often fail to increase the autonomy and discretion of local governments in these dimensions. In addition, they fall short of improving accountability incentive structures that are crucial to obtain more responsive and accountable local governance.

In Turkey, the policy objective of the second generation local government reform was to achieve economies of scale in the delivery of municipal services through amalgamation of municipalities and dissolution of SPAs and villages. ${ }^{33}$ Overall the changes failed to strengthen downward accountability linkages and enhancing the participation of vulnerable groups in local governance. Furthermore, they were introduced in a very top-down manner without any consultation with broader stakeholders; nearly half of the municipalities were abolished without holding referendum or consulting to the citizens.

Indirect election of metropolitan municipal councilors, existence of 10 percent threshold as well as the lack of quotas for vulnerable groups and women are major weaknesses the reforms could have addressed. On a positive note, however, the extension of the metropolitan municipality boundaries symbolically brings the elected metropolitan municipality mayor to the same level as the appointed governor of the province.

In terms of administrative system, the new legislation established a directorate of investment monitoring and coordination (DIMC) in metropolitan municipal areas to coordinate investment decisions. It is too early to make judgement call about DIMCs but from the outset it seems one type of local unit - SPA - has been replaced with another - DIMC - without elected leadership.

In terms of fiscal discretion and accountability, the extension of geographic boundaries of municipalities without reforming service delivery responsibilities was a missed opportunity to address the confusion in service delivery responsibilities between district and metropolitan municipalities. The recent changes have also failed to address the fluctuation of local government revenues and the reliance of metropolitan municipalities on transfer revenues. The Municipalities

3330 SPAs, 1591 municipalities and 16082 villages were dissolved. 
Law no 6360 introduced major changes in the percentages of general tax revenues going to local governments. These changes have increased the share of intergovernmental transfers in total revenues for all types of local governments. The increase is most significant in metropolitan municipalities where more than 75 percent of total revenues come from transfers. The preliminary results show that the recent changes in the design of the intergovernmental fiscal system do not strengthen fiscal autonomy of local governments. On the contrary, local governments are becoming heavily dependent on central government transfers. The decline in the share of ownsource revenues weakens the downward accountability linkage towards citizens. The only positive aspect of these changes is that there is no conditionality imposed on transfer revenues-they are mainly unconditional for municipalities.

Last but not least, the biggest challenge for Turkey is to avoid clientelistic and patronage politics at the local level. In-kind and cash handouts in return for votes is a major setback for efforts to strengthen downward accountability. More importantly, the increased role of TOKI in local affairs is major concern for corruption watchers.

All in all, it is impossible to unequivocally say that the recent changes have had a positive effect on local discretion and accountability in Turkey. As a matter of fact, with the worsening of the dependence of metropolitan municipalities on transfer revenues and deterioration of accountability and transparency institutions, one may say that these changes might have worsened local discretion and accountability.

\section{References}

Akilli, H. and Akilli, H. S. (2014). Decentralization and recentralization of local governments in Turkey. Procedia Social and Behavioral Sciences 140: 682-686.

Arıkboğa, E. (2013). Gecmişten Geleceğe Büyüksehir Belediye Modeli (From the past to the future Metropolitan Municipal Model). Yerel Politikalar 3 (1): 48-96.

Arıkboğa, E. (2014). Büyüksehir Belediye Meclislerindeki Temsil Adaletsizliğinin Coğrafi ve Siyasi Görünümleri (Geographical and Political Outlook of Representation Injustice in Metropolitan Municipality Councils). Marmara Üniversitesi Siyasal Bilimler Dergisi, 2 (2): 35-61.

Arıkboğa, Ü. 2015. Türkiye'de Büyüksehir Belediyesi Transfer Sistemi ve 6360 Sayılı Kanunun Etkileri (The Metropolitan Municipality Transfer System in Turkey and the Effects of Law No.6360). İ.I.B.F. Dergisi 37 (2): 1-39.

Aslam, G., and Yilmaz S. (2011). Impact of Decentralization Reforms in Pakistan on Service Delivery - An Empirical Analysis. Public Administration and Development 31 (3): 159-171.

Aytac, S. E. (2014). Distributive Politics in a Multiparty System: The Conditional Cash Transfer Program in Turkey. Comparative Political Studies 47 (9): 1211-1237.

Basbakanlik. (2005). Türkiye’de Yonetimler Arası Mali İlişkiler: Sorunlar ve Çözüm Önerileri (Intergovernmental Fiscal Relations in Turkey: Problems and Solution Recommendations). Ankara.

Bayraktar, S. U., and Altan, C. (2013). Explaining Turkish Party Centralism: Traditions and Trends in the Exclusion of Local Party Offices in Mersin and Beyond. In Negotiating Political Power in Turkey: Breaking Up the Party by Elise Massicard and Nicole Watts (eds) Routledge, Oxon: 17-36. 
Blom-Hansen, J., Houlberg, K., Serritzlew, S., and Triesman, D. (2016). Jurisdiction Size and Local Government Policy Expenditure: Assessing the Effect of Municipal Amalgamation. American Political Science Review 110 (4): 812-831.

Dahl, R. E. and Tufte, R. (1973). Size and Democracy. Stanford: Stanford University Press.

Ebel, R. D. and Taliercio, R. (2005). Subnational Tax Policy and Administration in Developing Countries. Tax Notes International: 919-936.

Edwards, B., Yilmaz, S., and Boex, J. (2015). Decentralization as a Post-Conflict Strategy: Local Government Discretion and Accountability in Sierra Leone. Public Administration and Development, 35: 46-60.

Eligur, B. (2009). Turkey's March 2009 Local Elections. Turkish Studies 10 (3): 469-496.

Falleti, T. (2005). A Sequential Theory of Decentralization: Latin American Cases in Comparative Perspective. American Political Science Review 99 (3): 327-346.

Fox, W. F., and Gurley, T. (2006). Will Consolidation Improve Sub-National Governments?. World Bank Policy Research Working Paper 3913, World Bank: Washington, D.C.

Gul, H., Kamalak, I., and Kiris, H. M. (2016). Local and Urban Administrations, Politics, and Elections in Turkey. In Comparative Studies and Regionally-Focused Cases Examining Local Governments, Sadioglu, U, Dede K (eds.) IGI Global: Pennsylvania: 182-206.

Guner A, and Yilmaz, S. (2006). Belediye Gelirlerinin Esneklik Analizi” (Buoyancy Analysis of Municipal Revenues). Legal Mali Hukuk Dergisi, 15: 673-685.

Gurakar, E. C. (2016). Politics of Favoritism in Public Procurement in Turkey. Palgrave Macmillan US: Basingstoke, United Kingdom.

Hooge, L., and Marks, G. (2009). Does Efficiency Shape the Territorial Structure of Government?. Annual Review of Political Science, 12: 225-241.

Kuran, H. (2015). Turk Yerel Yönetim Sisteminde Yeni Bir Kurum: Yatırım İzleme ve Koordinasyon Başkanlığ (A New Institution in the Turkish Local Government System: Directorate of Investment Monitoring and Coordination). Kayfor Bildiri Kitabi: Konya: 207-218.

Local Development International. (2013). The Role of Decentralisation/Devolution in Improving Development Outcomes at the Local Level: A Review of the Literature and Selected Cases. UK Department for International Development, London.

Marschall, M., Aydogan, A., and Bulut, A. (2016). Does Housing Create Votes? Explaining the Electoral Success of the AKP in Turkey. Electoral Studies 42: 201-212.

Mahieu, S, and Yilmaz, S. (2010). Local government discretion and accountability in Burkina Faso. Public Administration and Development 30 (5):329-344.

Ministry of Finance. General Directorate of Budget and Fiscal Control, http://www.bumko.gov.tr

Ministry of Finance. General Directorate of Public Accounts, www.muhasebat.gov.tr

Ministry of Interior. General Directorate of Local Authorities, General Activity Report for Local Authorities, 2012 and 2014.

Sadioglu, U., Dede, K., and Yuceyilmaz, A. A. (2016). The Significance of the 2014 Local elections in Turkey for Decentralization and Local Autonomy. In Comparative Studies and Regionally-Focused Cases Examining Local Governments, Sadioglu, U, Dede K (eds.) IGI Global: Pennsylvania: 182-206.

Savas-Yavuzcehre, P. (2016). The Effects of the Law No. 6360 on Metropolitan Municipality System in Turkey. European Scientific Journal August: 291-303.

Sayari, S. (2014). Interdisciplinary Approaches to Political Clientelism and Patronage in Turkey. Turkish Studies, 15 (4): 655-670. 
Schneider, A. (2003). Decentralization: conceptualization and measurement. Studies in Comparative International Development 38 (3): 32-57.

Smoke, Paul. (2015a). Rethinking Decentralization: Assessing Challenges to a Popular Public Sector Reform. Public Administration and Development. 35 (2): 97-112.

Smoke, Paul. (2015b). Managing Public Sector Decentralization in Developing Countries: Moving Beyond Conventional Recipes. Public Administration and Development. 35 (4): 250-262.

Triesman, D. (2007). The Architecture of Government: Rethinking Political Decentralization. Cambridge, UK: Cambridge University Press.

Venugopal, V., and Yilmaz, S. (2009). Decentralization in Kerala: panchayat government discretion and accountability. Public Administration and Development 29: 316-329.

Venugopal, V., and Yilmaz, S. (2010). Decentralization in Tanzania: an assessment of local government discretion and accountability. Public Administration and Development 30 (3): 215-230.

Yilmaz S., Beris, Y., and Serrano-Berthet R. (2010). Linking Local Government Discretion and Accountability in Decentralization. Development Policy Review 28 (3): 259-293.

Yilmaz, S., and Venugopal, V. (2010). Obstacles to decentralization in Ethiopia: political control versus discretion and accountability. In Decentralization in Developing Countries Global Perspectives on the Obstacles to Fiscal Devolution, Martinez-Vazquez J, Vaillancourt F (eds). Edward Elgar: Massachusetts: 466-489.

Yilmaz, S., and Venugopal, V. (2013). Local Government Discretion and Accountability in the Philippines. Journal of International Development, 25 (2): 227-250.

Yilmaz, S. (2009). Decentralization in Ghana: Local government discretion and accountability. Regional Development Studies, 13: 62-83

Yilmaz, S., and Guner, A. (2013). Local Government Discretion and Accountability in Turkey. Public Administration and Development, 33 (2): 125-142. 
